\title{
TEPUNG IKAN PETEK (Leiognathus equulus) SEBAGAI ADITIF PROTEIN PADA MI KERING LABU KUNING (Cucurbita moschata D.)
}

\section{Ponyfish Flour (Leiognathus equulus) as a Protein Additive in Dry Pumpkin Noodles (Cucurbita moschata D.)}

\author{
Meda Canti*, Sherly Apryani, dan Diana Lestari \\ Program Studi Teknologi Pangan, Fakultas Teknobiologi, Universitas Katolik Indonesia Atma Jaya, \\ Jalan Jenderal Sudirman 51, Jakarta 12930, Indonesia \\ *Korespondensi Penulis: meda.canti@atmajaya.ac.id \\ Diterima: 14 Januari 2020 ; Direvisi: 2 Juli 2020; Disetujui: 3 Agustus 2020
}

\begin{abstract}
ABSTRAK
Mi kering adalah produk pangan dari tepung terigu yang banyak dikonsumsi masyarakat. Produk ini dapat dikembangkan dengan tambahan dari bahan lain, seperti labu kuning (Cucurbita moschata), untuk mengurangi kebutuhan tepung terigu. Campuran antara tepung terigu dan $C$. moschata memiliki kandungan karbohidrat yang tinggi, namun rendah protein. Oleh karena itu, diperlukan penambahan bahan baku lain, seperti tepung ikan, untuk meningkatkan nilai gizinya. Ikan petek (Leiognathus equulus) dapat ditambahkan sebagai sumber protein dalam pembuatan mi kering. Penelitian ini bertujuan untuk mengevaluasi kualitas sensoris, fisik, dan proksimat, dari mi kering yang dibuat dengan kombinasi tepung terigu dan C. moschata, serta ditambahkan dengan tepung $L$. equulus. Formulasi mi kering dilakukan pada lima variasi rasio antara tepung terigu dan $C$. moschata (100:0, 90:10, 80:20, 70:30, dan 60:40). Formulasi terbaik yang didapatkan selanjutnya ditambahkan dengan variasi rasio tepung $L$. equulus $(0 \%, 10 \%, 20 \%, 30 \%$, dan $40 \%$ ). Hasil penelitian memperlihatkan bahwa mi kering dengan rasio tepung terigu dan $C$. moschata sebesar 80:20 serta tepung $L$. equulus hingga $20 \%$ adalah yang terbaik. Penambahan tepung $L$. equulus yang lebih tinggi menyebabkan penurunan daya serap air, swelling index, dan kuat tarik mi kering, serta peningkatan cooking loss dan kekerasan. Penambahan $20 \%$ tepung $L$. equulus meningkatkan kandungan protein mi kering sebesar 1,52 kali; menjadi 20,74 $\pm 1,22 \%$ (dry basis/db).
\end{abstract}

KATA KUNCI : ikan petek, labu kuning, mi kering, protein, tepung, terigu.

\begin{abstract}
Dried noodle is a daily consumed food from wheat flour. This product can be developed with the addition of other ingredients, such as pumpkin (Cucurbita moschata), to reduce the needs of wheat flour. The mixture between wheat flour and $\underline{C}$. moschata has a high carbohydrate content but low protein. Therefore, it is necessary to add other raw materials, such as fish flour, to increase the nutritional value. Pony fish (Leiognathus equulus) can be added as a source of protein for dried noodles. This study aimed to evaluate the sensory quality, physical, and proximate value of dry noodles made from the combination of wheat flour and $\underline{C}$. moschata, which was also added with $\underline{L}$. equulus flour. Formulation of dry noodles was conducted with five ratio variations between wheat flour and $\underline{\text { C. moschata }}$ (100:0, 90:10, 80:20, 70:30, and 60:40). The best ratio was then added with varied $\underline{L}$. equulus flour $(0 \%, 10 \%, 20 \%, 30 \%$, and $40 \%)$. The results showed that the best formula for dry noodles was the ratio of wheat flour and $\underline{C}$. moschata at 80:20 and $\underline{\underline{L}}$. equulus up to $20 \%$. Higher addition of $\underline{L}$. equulus flour decreased water absorption, swelling index, the tensile strength of dry noodles, and increased cooking loss and hardness. The addition of $20 \%$ of L. equulus flour increased the protein content of dry noodles by 1.52 times, to $20.74 \pm 1.22 \%$ (dry basis/db).
\end{abstract}

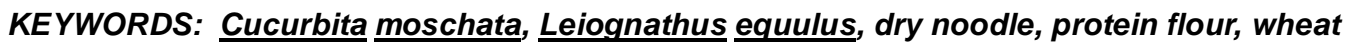

\section{PENDAHULUAN}

Mi kering merupakan produk pangan yang mengandung karbohidrat dalam jumlah tinggi dan sering dikonsumsi oleh masyarakat Indonesia. Mi kering, yang umumnya terbuat dari tepung terigu, dikonsumsi sebesar $78 \mathrm{~g} / \mathrm{kapita} / \mathrm{tahun}$ atau $1,50 \mathrm{~g} /$ kapita/minggu. Pengembangan produk mi kering dari bahan lain, salah satunya dari labu kuning (Cucurbita moschata), dapat menjadi alternatif substituen tepung 
terigu untuk memenuhi tingkat konsumsi yang tinggi tersebut. Produksi $C$. moschatadi Indonesia mencapai 523.063 ton, dengan tingkat konsumsi sebesar 466.400 ton (Fauzi, Diniyah, Rusdianto, \& Kuliahsari, 2017; Kementerian Pertanian, 2018). Selain itu, kadar karbohidratnya mencapai $83,18 \%$; sehingga potensial sebagai alternatif tepung terigu (Gumolung, 2019).

Penelitian sebelumnya telah menemukan bahwa kadar protein mi kering yang dibuat dari tepung terigu adalah 8,25\% (wet basis/wb) dan mi kering dari 10$30 \%$ tepung C. moschata adalah $7,83-7,81 \%$ wb (Aukkanit \& Sirichokworrakit, 2017). Penelitian lainnya juga menunjukkan penurunan kadar protein pada adisi tepung C. moschata sebesar $20-40 \%$ dalam mi kering; yaitu dari $13,36 \%$ menjadi 10,77 $11,97 \%$ wb (Anam \& Handajani, 2010). C. moschata diketahui hanya memiliki kadar protein sebesar 4,28\% (Gumolung, 2019). Hal inilah yang menyebabkan penurunan kandungan protein pada mi kering. Oleh karena itu, diperlukan adisi bahan lain sebagai sumber protein. Hal yang selaras juga dibutuhkan untuk peningkatan gizi produk mi kering lain yang ada di pasaran.

Sumber alternatif protein hewani pada pembuatan mi kering adalah tepung ikan. Tingkat konsumsi ikan di Indonesia pada tahun 2018 adalah 50,69 kg/kapita/ tahun (Kementerian Kelautan \& Perikanan, 2018). Aplikasi tepung ikan sebagai bahan aditif untuk meningkatkan kandungan protein telah digunakan pada produk mi dan pasta. Contohnya adalah tepung ikan lele dumbo, motan, kod merah, dan juga cakalang (Desai, Brennan, \& Brennan, 2018; Irsalina, Lestari, \& Herpandi, 2016; Yulianti, 2018; Zuhri, Swastawati, \& Wiayanti, 2014).

Jenis ikan yang juga potensial sebagai bahan aditif untuk meningkatkan kadar protein produk mi kering adalah petek (Leiognathus equulus). Ikan ini memiliki kandungan protein tinggi; yang dapat mencapai hingga $66,58 \%$ (Priatni et al., 2018). L. equulus juga mengandung omega tiga asam eikosapentanoat/EPA dan asam dokosaheksaenoat/DHA yang tinggi; yaitu sebesar 5,3\% dan 5,8\% (Chandrani \& Wattevidanage, 2016). Produksi ikan ini mencapai 22.644 ton/tahun di Indonesia (BPS Kota Semarang, 2017). Namun, pemanfaatan ekonomis $L$. equulus belum optimal. Pemanfaatan tepung $L$. equulus sebagai bahan aditif untuk meningkatkan protein pada mi kering adalah aplikasi yang potensial. Hal inilah yang mendasari dilaksanakannya penelitian ini. Riset bertujuan untuk melakukan evaluasi dari kualitas sensoris, fisik, dan proksimat, dari mi kering dengan bahan subtituen terigu, yaitu tepung C.moschata, dan bahan aditif tepung $L$. equulus.

\section{BAHAN DAN METODE}

\section{Bahan}

Bahan utama yang digunakan dalam penelitian ini adalah $L$. equulus berukuran $2,20-21,20 \mathrm{~cm}$. Ikan ini diperoleh dari Pasar Baru (Bekasi), yang merupakan tangkapan nelayan dari perairan Teluk Jakarta. Bahan lainnya adalah labu kuning ( $C$. moschata) dengan bobot 2,5-5 kg. Sampel ini diperoleh dari Total Buah Segar (Bekasi), yang merupakan hasil pertanian Karawang, Jawa Barat. Selain itu, bahan yang dipergunakan dalam penelitian adalah tepung terigu (Cakra Kembar, PT Bogasari), jeruk nipis, natrium metabisulfit (Aditya Birla Chemicals), garam alkali $\left(\mathrm{Na}_{2} \mathrm{CO}_{3}\right.$ dan $\mathrm{K}_{2} \mathrm{CO}_{3}$ - Merck), dan bahan-bahan pengujian bahan analisis proksimat dengan kualitas Pro Analysis (Merck).

\section{Metode}

\section{Pembuatan tepung ikan petek (L. equulus)}

Pembuatan tepung ikan $L$. equulus dilakukan menurut metode Nuringtyas dan Adi (2017). Ikan dibersihkan dari kotoran dan selanjutnya dipisahkan bagian kepala dan ekornya. Bagian tubuh ikan lalu direndam dalam 15\% air jeruk nipis dengan rasio 1:1 (berat/volume) selama 30 menit untuk mengurangi aroma amis. Ikan kemudian dikukus dalam panci pengukus (Orchid MTA-2439366) pada suhu $100^{\circ} \mathrm{C}$ selama 30 menit. Selanjutnya, daging ikan dilumatkan dengan food processor (Philips HR-7627) dan dikeringkan dalam oven (Memmert UN 110) pada suhu $60^{\circ} \mathrm{C}$ selama $20 \mathrm{jam}$. Hasil pengeringan ini kemudian dihaluskan menggunakan food processor (Philips HR7627) dan diayak pada ukuran 60 mesh.

\section{Pembuatan tepung labu kuning (C. moschata)}

Pembuatan tepung C. moschata dilakukan dengan metode Purwanto, Ishartani, dan Rahadian (2013). Pada tahap awal, dilakukan pengupasan kulit, pemisahan dari biji, pencucian, dan pemotongan hingga ukurannya menjadi kecil. Selanjutnya, bahan baku direndam dalam 0,25\% natrium metabisulfit selama 30 menit untuk menstabilkan warna buah dan mencegah reaksi pencoklatan karena enzimatis (melanin) dan non-enzimatis (melanoidin). Setelah itu, bahan dikeringkan dalam oven (Memmert UN 110) pada suhu $60^{\circ} \mathrm{C}$ selama 41 jam, lalu dihaluskan menggunakan food processor (Philips HR-7627), dan terakhir diayak pada 60 mesh.

\section{Formulasi mi kering}

Penentuan komposisi bahan baku untuk mi kering yang terbaik dilakukan dengan dua tahap dan tiga 
ulangan. Formulasi tahap pertama adalah untuk mementukan komposisi tepung terigu dan $C$. moschata terbaik. Pada formulasi ini, mi kering dibuat dengan komposisi tepung terigu : tepung C. moschata sebesar sebesar 100:0, 90:10, 80:20, 70:30, dan 60:40. Kadar tepung C. moschata yang tidak lebih dari $40 \%$ didasari dari prapercobaan dan penelitian Purwandari et al. (2014), yang menunjukkan penggunaan tepung $C$. moschata tinggi akan menyebabkan mi kering dengan warna sangat kuning tua, sangat beraroma dan terasa C. moschata, tekstur tidak kenyal, mudah putus, serta kekerasan, kelengketan, dan cooking loss yang tinggi.

Pengujian sensoris dilakukan untuk mendapatkan formulasi rasio bahan baku tepung terigu dan $C$. moschata terbaik, sebagai komposisi dasar yang digunakan pada formulasi tahap kedua. Formulasi tahap ini adalah pencampuran komposisi tepung terigu dan $C$. moschata terbaik dengan variasi tepung $L$. equulus sebesar $0 \%, 10 \%, 20 \%, 30 \%$, dan $40 \%$. Konsentrasi penambahan tepung $L$. equulus yang tidak melebihi $40 \%$ didasari oleh prapercobaan dan Yulianti (2018), yang menunjukkan penggunaan tepung $L$. equulus dalam jumlah tinggi menyebabkan mi kering berwarna kuning tua/kecoklatan, beraroma sangat amis, sangat terasa ikan, memiliki aftertaste sangat kuat, mudah putus, serta bertekstur lembek, tidak kenyal, dan tidak padat.

Formulasi tepung ditambahkan 100:1 antara air dan garam alkali $\left(\mathrm{Na}_{2} \mathrm{CO}_{3}\right.$ dan $\mathrm{K}_{2} \mathrm{CO}_{3}$ pada perbandingan 3:2), untuk memperbaiki tekstur dan kekenyalan, sehingga adonan menjadi kalis (Santosa, 2009). Adonan diaduk hingga homogen secara manual selama 7-8 menit, lalu dibuat menjadi lembaran dan dipotong menjadi bentuk mi dengan noodles maker (Oxone OX-989N). Tahap selanjutnya adalah proses pengukusan dalam panci kukusan (Orchid MTA2439366) dengan suhu $100^{\circ} \mathrm{C}$ selama 10 menit agar mi menjadi kenyal dan lembut. Mi kemudian didinginkan 10-15 menit untuk menghilangkan uap panas yang menempel, kemudian dikeringkan menggunakan oven (Memmert UN 110) pada suhu $60^{\circ} \mathrm{C}$ selama 3 jam.

\section{Analisis sensori, fisik dan proksimat}

Analisis sensoris dilakukan dengan uji hedonik oleh 25 panelis semi terlatih (Larmond, 1973). Analisis ini dilakukan pada mi kering yang sudah dimasak. Analisis fisik meliputi daya serap air, swelling index, dan cooking loss berdasarkan metode Biyumna, Windrati, dan Diniyah (2017); Jang, Bae, dan Lee (2015); dan Kong et al. (2012). Kekerasan dan kuat tarik diuji dengan texture analyser (Agrosta). Sementara itu, analisis proksimat, yang meliputi kadar air, abu, protein, lemak, dan karbohidrat, didasari metode AOAC
(2000; 2002; 2005). Analisis proksimat mi kering dilakukan terhadap formulasi terbaik antara tepung terigu dan $C$. moschata yang ditambahkan dengan variasi konsentrasi tepung $L$. equulus. Replikasi dari keseluruhan pengujian adalah dua ulangan.

\section{Analisis data}

Analisis data terhadap karakteristik formulasi pertama dan kedua menggunakan rancangan acak lengkap (RAL) pada satu faktor. Analisis keragaman (ANOVA) dan Duncan's Multiple Range Test (DMRT) diuji pada tingkat signifikasi $95 \%$ menggunakan perangkat lunak SPSS Versi 24.

\section{HASIL DAN PEMBAHASAN}

\section{Analisis Sensoris Formulasi Mi Kering Masak Substitusi Tepung Terigu dengan Tepung $C$. moschata}

Hasil uji hedonik menunjukkan bahwa mi kering dengan rasio tepung terigu : $C$. moschata sebesar 80:20 masih dapat diterima oleh panelis (Gambar 1). Atribut warna, aroma, rasa, tekstur, dan kesukaan keseluruhan tidak berbeda nyata $(p>0,05)$ dengan mi kering kontrol 100:0 dan 90:10. Mi kering yang terbuat dari rasio tepung terigu : C. moschata sebesar 70:30 dan 60:40 memiliki karakteristik warna dan kesukaan keseluruhan yang berbeda nyata $(p<0,05)$ dengan mi kering kontrol 100:0, 90:10, dan 80:20, sedangkan dalam atribut aroma dan tekstur tidak berbeda nyata $(p>0,05)$ dengan mi kering 80:20. Mi kering dengan rasio tepung terigu : $C$. moschata sebesar 70:30 juga tidak berbeda nyata $(p>0,05)$ dengan mi kering 80:20 dalam atribut aroma, rasa, dan tekstur.

Mi kering dengan rasio 80:20 memiliki warna kuning, agak beraroma, terasa C. moschata, dan memiliki tekstur agak kenyal. Hal ini sesuai dengan penelitian Aukkanit dan Sirichokworrakit (2017) yang menyatakan bahwa penambahan tepung $C$. moschata hingga $20 \%$ masih dapat diterima oleh panelis dengan atribut yang tidak berbeda nyata $(p>0,05)$ dengan mi kering kontrol 100:0 dan 90:10. Sebaliknya, mi kering dengan rasio 60:40 dan 70:30 memiliki warna kuning tua, beraroma dan terasa C. moschata, serta teksturnya tidak kenyal. Oleh karena itu, uji sensoris ini memperlihatkan bahwa rasio tepung terigu dan tepung C. moschata terbaik adalah 80:20. Semakin tinggi substitusi tepung $C$. moschata dalam pembuatan mi kering akan merubah karakteristik warna, aroma, dan rasa, sehingga menurunkan angka penerimaan panelis.

Tepung C. moschata memiliki kandungan pati sebesar $25,10 \pm 0,32 \%$ dry basis/db dan amilosa 


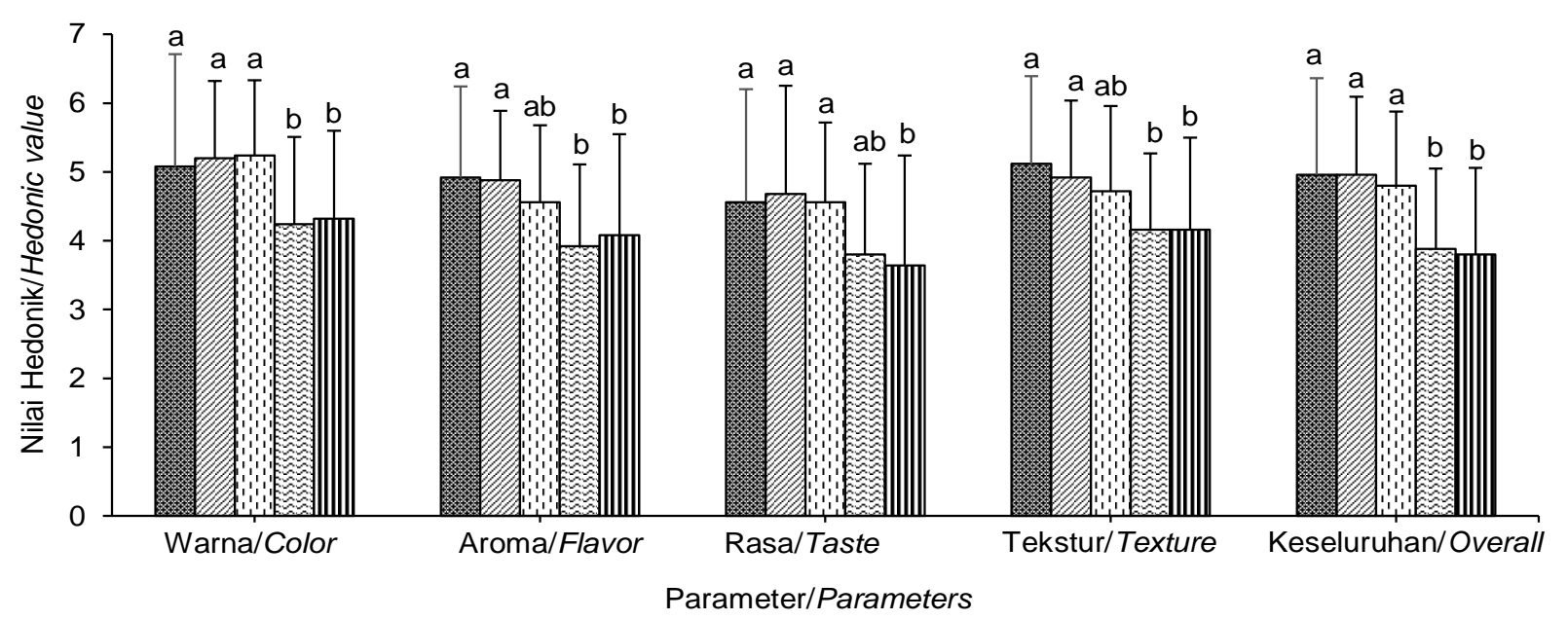

图 TT (Tepung Terigu/Wheat Flour) : TLK (Tepung C. moschata/C. moschata Flour) $=100: 0$

๑ TT (Tepung Terigu/Wheat Flour) : TLK (Tepung C. moschata/C. moschata Flour) $=90: 10$

$\square$ TT (Tepung Terigu/Wheat Flour) : TLK (Tepung C. moschata/C. moschata Flour) $=80: 20$

๑ TT (Tepung Terigu/Wheat Flour) : TLK (Tepung C. moschata/ $\underline{C}$. moschata Flour) $=70: 30$

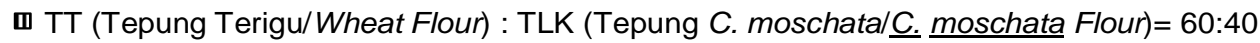

Keterangan/Note:

* Huruf berbeda menunjukkan perbedaan yang signifikan $(p<0,05) /$ Different letters indicate significant difference $(p<0.05)$

** Nilai hedonik: $1=$ sangat tidak suka; $2=$ tidak suka; $3=$ agak tidak suka; $4=$ netral; $5=$ agak suka; $6=$ suka; $7=$ sangat suka/Hedonic values: 1. Dislike very much; 2. Dislike; 3. Dislike slightly; 4. Neither like nor dislike; 5. Like slightly; 6. Like; 7. Like very much

Gambar 1. Hasil uji hedonik terhadap mi kering matang dengan formulasi tepung terigu dan tepung $C$. moschata

Figure 1. Hedonic test on cooked dried noodles formulated by wheat flour and $\underline{\text { C. }}$ moschata flour

$1,77 \pm 0,19 \%$ db (Nakhon, Jangchud, Jangchud, \& Prinyawiwatkul, 2017). Kadar amilosa ini menyebabkan rendahnya viskositas maksimum, sulit teretrogradasi, struktur gel yang lemah, dan peningkatan cooking loss (Charles, Chang, Ko, Sriroth, \& Huang, 2005; Setyani, Astuti, \& Florentina, 2017). C. moschatajuga mengandung b-karoten $(7,56$ $\mathrm{mg} / 100 \mathrm{~g} \mathrm{db}$ ); yang menyebabkan warnanya menjadi kuning kecoklatan dengan nilai $\mathrm{L}^{*}$; $a^{*}$; dan $b^{*}$ sebesar 76,72; 0,59; dan 33,71 (Khan, Mahesh, Vineeta, Sharma, \& Semwal, 2019; Nakhon et al. 2017: Wongsagonsup, Kittisuban, Yaowalak, \& Suphantharika, 2015). Selain itu, C. moschata memiliki matriks gluten rendah dan water holding capacity tinggi $(5,70 \pm 0,09 \mathrm{~g} / \mathrm{g})$, sehingga proporsinya yang tinggi di mi kering akan menyebabkan tekstur yang tidak kenyal, keras, dan mudah patah (Ahmed, Qazi, \& Jamal, 2015; Kuchtová, Karovièová, Kohajdová, \& Minarovièová, 2016). Oleh karena itu, penambahannya yang optimal adalah hingga $20 \%$.

\section{Analisis Sensoris Formulasi Mi Kering Masak Substitusi Tepung Terigu dengan Tepung $C$. moschata dan Tepung $L$. equulus}

Hasil analisis sensoris secara keseluruhan menunjukkan bahwa penambahan tepung $L$. equulus hingga $20 \%$ masih dapat diterima oleh panelis (Gambar 2). Atribut warna, aroma, rasa, tekstur, aftertaste, dan kesukaan keseluruhan mi pada penambahan tepung $L$. equulus sebesar $20 \%$ tidak berbeda secara signifikan $(p>0,05)$ dengan penambahan $10 \%$. Penambahan lebih tinggi ( $30 \%$ dan $40 \%$ ) menyebabkan atribut warna, aroma, rasa, dan kesukaan keseluruhan yang berbeda nyata $(p<0,05)$ dengan penambahan $20 \%, 10 \%$, dan kontrol. Sementara itu,atribut aftertaste 30\% dan $40 \%$ tidak berbeda nyata $(p>0,05)$ terhadap penambahan $20 \%$.

Penambahan tepung ikan sebesar $30 \%$ dan $40 \%$ tidak disukai oleh panelis, karena mi yang dihasilkan memiliki aroma, rasa, dan aftertasteikan, serta tekstur 
yang tidak kenyal, sebagai karakteristik dari tepung $L$. equulus yang berwarna putih keabuan tersebut. Oleh karena itu, pada konsentrasi yang tinggi, tepung ini akan menyebabkan penurunan tingkat penerimaan. Selain itu, tekstur mi yang dihasilkan semakin kurang kenyal karena tepung ikan tidak mengandung gluten, sebagai komponen penting yang mempengaruhi tekstur mi. Penambahan tepung ikan dalam jumlah tinggi juga menyebabkan peningkatan tingkat kekerasan mi kering; akibat kandungan proteinnya yang dapat mencapai $50,03 \pm 0,59 \% \mathrm{db}$. Denaturasi protein pada suhu tinggi saat dimasak akan mengakibatkan tekstur mi yang kaku dan keras (Setiyoko, Nugraheni, \& Hartutik, 2018).

Hasil uji sensoris formulasi tahap pertama dan kedua menunjukkan penilaian panelis secara keseluruhan antara 4,28 $\pm 1,06-5,52 \pm 0,92$ (agak suka). Konsentrasi tepung C. moschata dan $L$. equulus yang tinggi akan menyebabkan penurunan nilai hedonik panelis, yaitu pada variabel warna, aroma, rasa, tekstur, dan aftertaste.

\section{Analisis Fisik Mi Kering}

Hasil analisis fisik menunjukkan bahwa peningkatan kadar tepung $L$. equulus menyebabkan penurunan daya serap air, swelling index, dan kuat tarik, serta peningkatan cooking loss dan kekerasan (Tabel 1). Daya serap air mi kering menurun sebanding dengan swelling index. Hal ini dipengaruhi oleh kadar protein tepung $L$. equulus. Kandungan protein yang tinggi menyebabkan terbentuknya ikatan kompleks dengan pati, sehingga penyerapan air terganggu dan pengembangan mi menjadi turun (Billina, Waluyo, \& Suhandy, 2014). Hal lainnya yang berhubungan dengan daya serap air adalah kekerasan. Peningkatan kekerasan pada kenaikan kadar tepung $L$. equulus terkait dengan kandungan air yang rendah, sehingga membuat mi menjadi keras (Desai et al., 2018).

Selain itu, peningkatan cooking loss pada mi selaras dengan kadar tepung $L$. equulus. Pengurangan kuantitas gluten pada kenaikan kadar tepung $L$. equulus menyebabkan penurunan kemampuan pembentukan jaringan tiga dimensi yang dapat menghambat keluarnya granula pati (Lanyala, Rahim, \& Samudin, 2018). Kandungan gluten juga terkait dengan parameter kuat tarik. Penurunan kadarnya pada adonan mi menyebabkan pengurangan ikatan gluten dan granula pati, sehingga mi menjadi mudah putus (Pratama \& Nisa, 2014).

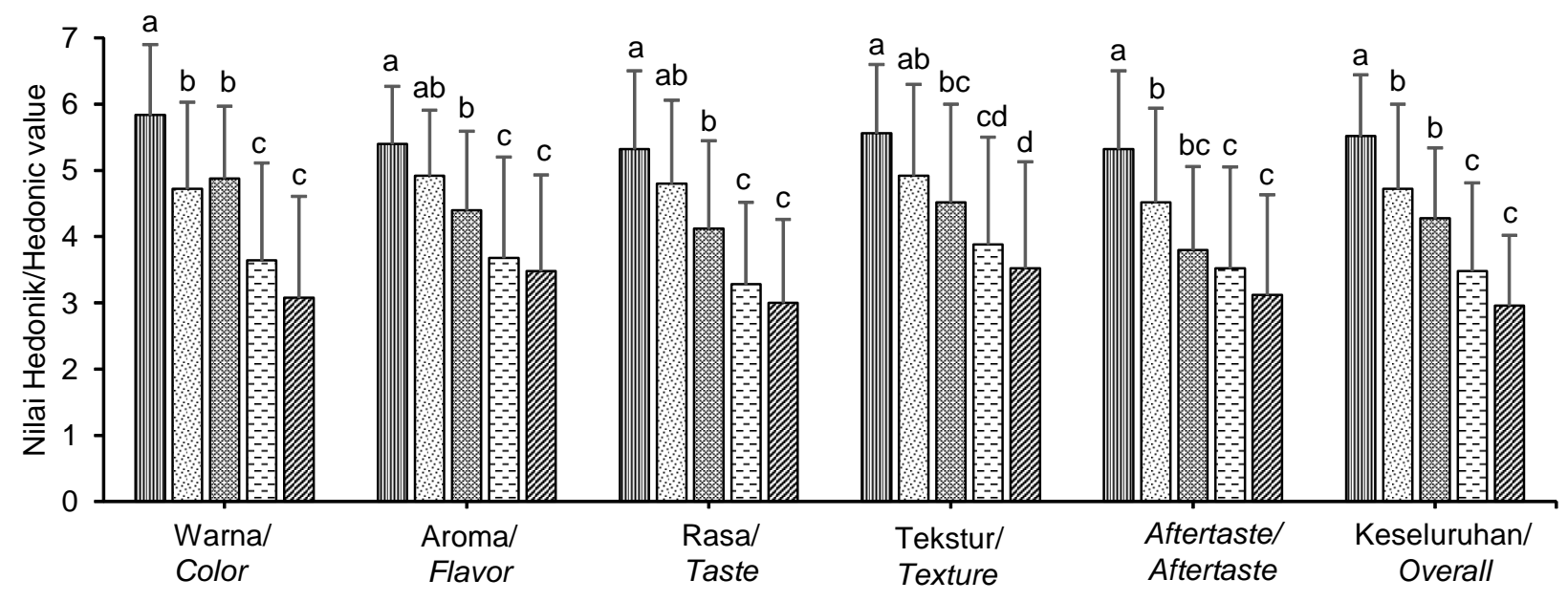

m Tepung $L$. equulus 0\%/L. equulus flour $0 \%$

๑ Tepung $L$. equulus $10 \% / \underline{L}$. equulus flour $10 \%$

* Tepung L. equulus 20\%/L. equulus flour $20 \%$

口 Tepung $L$. equulus $30 \% /$ L. equulus flour $30 \%$

(a) Tepung $L$. equulus $40 \%$ /L. equulus flour $40 \%$

Keterangan/Note:

* Huruf berbeda menunjukkan perbedaan yang signifikan $(p<0,05) /$ Different letters indicate significant difference $(p<0.05)$

** Nilai hedonik: $1=$ sangat tidak suka; $2=$ tidak suka; $3=$ agak tidak suka; $4=$ netral; $5=$ agak suka; $6=$ suka; $7=$ sangat suka/Hedonic value: 1. Dislike very much; 2. Dislike; 3. Dislike slightly; 4. Neither like nor dislike; 5. Like slightly; 6. Like; 7. Like very much

Gambar 2. Hasil uji hedonik terhadap mi kering matang dengan formulasi tepung terigu dan $C$. moschata (80:20) serta variasi tepung $L$. equulus

Figure 2. Results of hedonic tests of cooked dried noodles formulated by wheat and C. moschata (80:20), and various $\underline{L}$. equulus flour concentrations 
Tabel 1. Hasil analisis fisik mi kering matang dengan formulasi tepung terigu dan C. moschata (80:20) serta variasi tepung $L$. equulus

Table 1. Results of physical analysis of cooked dried noodles which formulated with wheat and $\underline{\text { C. moschata }}$ (80:20), and various L. equulus flour concentrations

\begin{tabular}{cccccc}
\hline $\begin{array}{c}\text { Tepung } \\
\text { L. equulus/ } \\
\text { L. Equulus }\end{array}$ & $\begin{array}{c}\text { Daya serap } \\
\text { air/Water } \\
\text { absorption } \\
\text { flour } \\
(\%)\end{array}$ & $\begin{array}{c}\text { Swelling } \\
\text { index }\end{array}$ & $\begin{array}{c}\text { Cooking } \\
\text { loss } \\
(\%)\end{array}$ & $\begin{array}{c}\text { Kekerasan/ } \\
\text { Hardness } \\
(\mathbf{g f})\end{array}$ & $\begin{array}{c}\text { Kuat Tarik/ } \\
\text { Tensile strength } \\
(\mathbf{g f})\end{array}$ \\
\hline 0 & $215.85 \pm 32.09^{\mathrm{a}}$ & $2.33 \pm 0.46^{\mathrm{a}}$ & $8.26 \pm 1.85^{\mathrm{a}}$ & $6,991.00 \pm 1,227.55^{\mathrm{a}}$ & $35.17 \pm 6.49^{\mathrm{a}}$ \\
10 & $190.35 \pm 24.55^{\mathrm{ab}}$ & $2.18 \pm 0.46^{\mathrm{a}}$ & $9.16 \pm 1.26^{\mathrm{ab}}$ & $7,250.50 \pm 351.13^{\mathrm{a}}$ & $27.00 \pm 6.45^{\mathrm{ab}}$ \\
20 & $185.99 \pm 21.82^{\mathrm{ab}}$ & $2.15 \pm 0.50^{\mathrm{a}}$ & $9.80 \pm 1.12^{\mathrm{abc}}$ & $7,366.33 \pm 478.10^{\mathrm{a}}$ & $23.00 \pm 11.06^{\mathrm{bc}}$ \\
30 & $175.99 \pm 26.17^{\mathrm{b}}$ & $2.04 \pm 0.48^{\mathrm{a}}$ & $10.27 \pm 1.11^{\mathrm{bc}}$ & $7,384.67 \pm 259.90^{\mathrm{a}}$ & $17.17 \pm 5.12^{\mathrm{c}}$ \\
40 & $172.59 \pm 21.55^{\mathrm{b}}$ & $1.98 \pm 0.36^{\mathrm{a}}$ & $11.54 \pm 2.05^{\mathrm{c}}$ & $7,418.00 \pm 492.68^{\mathrm{a}}$ & $15.50 \pm 9.78^{\mathrm{c}}$ \\
\hline
\end{tabular}

Keterangan/Note :

Huruf berbeda pada kolom yang sama menunjukkan perbedaan yang signifikan $(p<0,05) /$ Different Letters in the same column shows a significant difference $(p<0.05)$

\section{Analisis Proksimat Mi Kering}

Hasil analisis proksimat menunjukkan bahwa penambahan tepung $L$. equulus akan meningkatkan kadar air, abu, protein, dan lemak, serta menurunkan kadar karbohidrat (Gambar 3). Mi kering dengan penambahan $20 \%$ tepung $L$. equulus memiliki kadar protein yang paling tinggi dan berbeda nyata $(p<0,05)$ dengan mi kering kontrol.
Kandungan kadar air pada tepung L. equulus mempengaruhi kandungan kadar air pada mi kering. Kadar air mi kering dengan penambahan hingga $20 \%$ tepung $L$. equulus masih memenuhi SNI mi kering, yaitu maksimal sebesar 13\% (BSN, 2015). Sementara itu, peningkatan kadar abu terjadi karena kadar abu tepung $L$. equulus lebih tinggi dari tepung terigu maupun C. moschata. L. equulus merupakan produk hewani, sehingga kandungan mineral seperti kalsium,

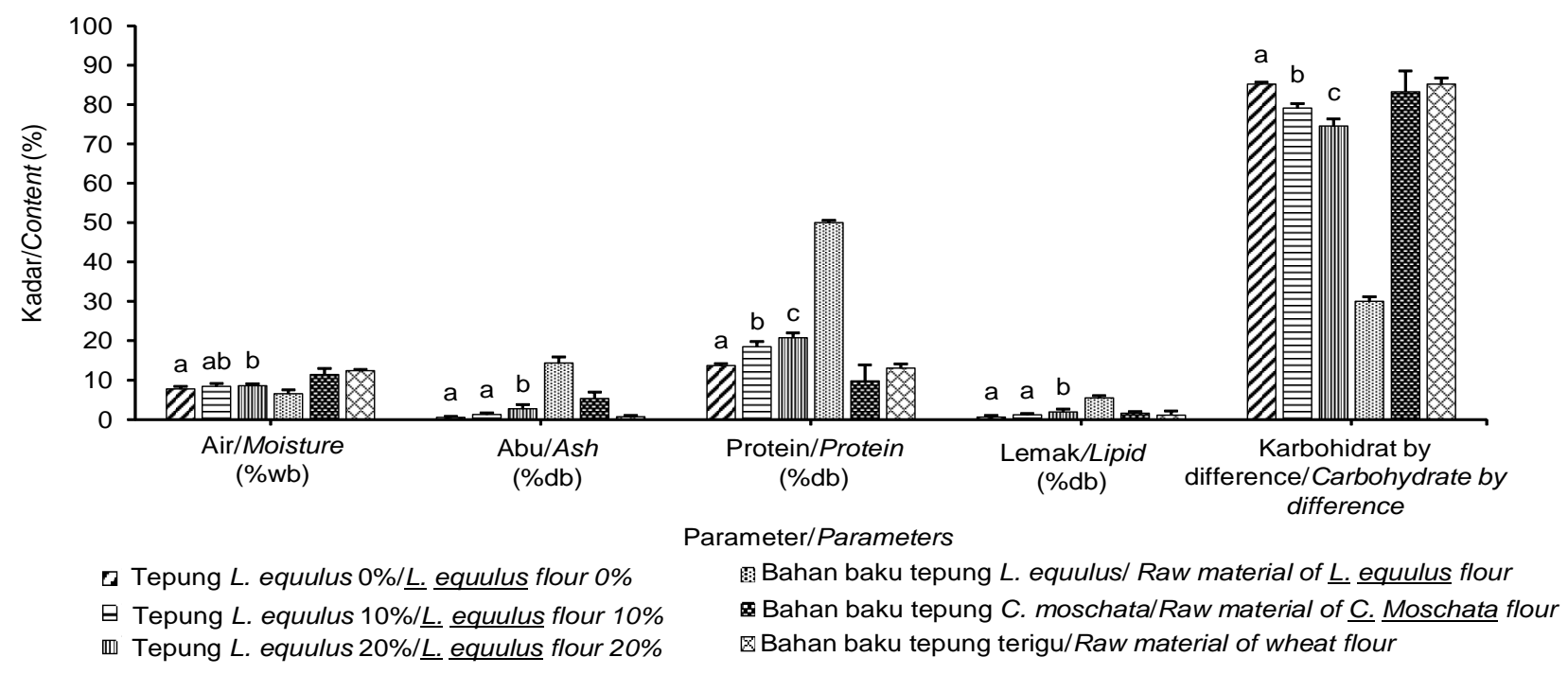

Keterangan/Note:

Perbedaan huruf menunjukkan perbedaan yang signifikan $(p<0,05) /$ Different letters indicate significant difference $(p<0.05)$

Gambar 3. Hasil analisis proksimat mi kering masak dengan formulasi tepung terigu dan C. moschata (80:20) serta variasi tepung $L$. equulus

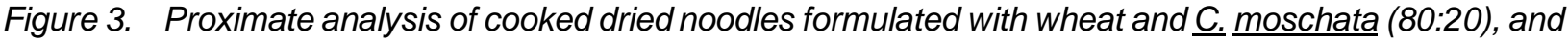
various L. equulus flour concentrations 
fosfor, dan besi, lebih tinggi dibandingkan dengan produk nabati (Irsalina et al., 2016). Data kadar ini juga masih memenuhi persyaratan SNI mi kering, yaitu maksimal sebesar 3\% (BSN, 2015).

Penambahan tepung C. moscata telah diketahui menurunkan kandungan protein pada mi kering. Kadar protein pada tepung ini hanya sebesar $6,06 \pm 1,83 \%$ db (Mardiah, Andini, Hafiani, Fitrilia, \& Widowati, 2020). Data bahan baku menunjukkan kadar protein L. equulus yang secara signifikan $(p<0,05)$ lebih tinggi $(50,03 \pm 0,59 \% \mathrm{db})$ dibandingkan dengan tepung $C$. moscata $(9,82 \pm 4,03 \% \mathrm{db})$ dan tepung terigu $(13,03 \pm 1,06 \% \mathrm{db})$. Penambahan $20 \%$ tepung ikan menyebabkan kadar protein mi kering menjadi $20,74 \pm 1,22 \%$ db. Nilai ini meningkat hingga 1,52 kali dibandingkan dengan mi kering kontrol. Selain itu, kadar protein juga telah melampaui SNI, yaitu minimal sebesar 10\% (BSN, 2015). Peningkatan kadar lemak juga terjadi karena bahan baku $L$. equulus mengandung lemak yang tinggi. Sebaliknya, penurunan kadar karbohidrat terdeteksi karena bahan baku $L$. equulus memiliki kandungan karbohidrat lebih rendah dibandingkan dengan tepung terigu dan $C$. moschata.

Penelitian selaras menunjukkan kandungan protein sebesar $13,37 \pm 0,27-17,52 \pm 0,59 \%$ pada mi kering mocaf dengan penambahan tepung ikan lele dumbo $10-20 \%$ (Zuhri et al., 2014). Sementara itu, mi kering ubi jalar dengan penambahan tepung ikan cakalang $20 \%$ memiliki kandungan protein sebesar $11,09 \%$; sedangkan penambahan tepung ikan tongkol $10-20 \%$ meningkatkan kadar protein mi menjadi 11,20-14,77\% (Pang, Noerhartati, \& Rejeki, 2013; Yulianti, 2018). Penambahan tepung $L$. equulus $10-20 \%$ pada mi kering $C$. moschatajuga memiliki kuat tarik yang lebih tinggi dibandingkan mi kering dengan penambahan tepung ikan lele dumbo (Zuhri et al., 2014). Oleh karena itu, hasil riset ini memperlihatkan bahwa mi kering $C$. moschata dengan penambahan tepung $L$. equulus sebesar $10-20 \%$ merupakan aplikasi yang potensial untuk meningkatkan kandungan gizi dan karakteristik mi kering, dibandingkan dengan jenis ikan lainnya, seperti lele dumbo, cakalang, dan tongkol.

\section{KESIMPULAN}

Pembuatan mi kering dengan menggunakan campuran antara tepung terigu, $C$. moschata dan $L$. equulus dapat mempengaruhi karakteristik mi yang dihasilkan. Perlakuan terbaik mi kering yang masih dapat diterima oleh panelis, dari atribut warna, aroma, rasa, tekstur, aftertaste, dan keseluruhan, adalah formulasi rasio tepung terigu dan $C$. moschata sebesar $80: 20$, serta $L$. equulus hingga $20 \%$. Mi kering dengan penambahan hingga $20 \%$ tepung $L$. equulus dapat meningkatkan kandungan protein hingga 1,52 kali dibandingkan dengan mi kering kontrol. Penelitian selanjutnya dapat dilakuan untuk pengujian umur simpan produk mi kering, sehingga dapat diketahui durasi waktu penurunan kualitas produk selama penyimpanan.

\section{UCAPAN TERIMA KASIH}

Terimakasih diberikan kepada Lembaga Penelitian dan Pengabdian Masyarakat (LPPM) Universitas Katolik Indonesia Atma Jaya, melalui program hibah penelitian Fakultas Teknobiologi.

\section{DAFTAR PUSTAKA}

Ahmed, I., Qazi, I. M., \& Jamal, S. (2015). Quality evaluation of noodles prepared from blending of broken rice and wheat flour. Starch Journal, 67(11-12), 905-912. doi: 10.1002/star.201500037

Anam, C., \& Handajani, S. (2010). Mi kering waluh (Cucurbita moschata) dengan antioksidan dan pewarna alami. Caraka Tani: Journal of Sustainable Agriculture, 25(1), 72-78. doi: 10.20961/ carakatani.v25i1.15744

Association of Official Analytical Chemists (AOAC). (2000). Official Methods of Analysis of AOAC (17 th ed.). Gaithersburg, US: AOAC International.

Association of Official Analytical Chemists (AOAC). (2002). Official Methods of Analysis. Protein (crude) in animal feed, forage (plant tissue), grain, and oilseeds. Virginia, US: AOAC Internatinal.

Association of Official Analytical Chemists (AOAC). (2005). Official methods of analysis of AOAC international (18 ${ }^{\text {th }}$ ed.). Mayland, US: AOAC International.

Aukkanit, N., \& Sirichokworrakit, S. (2017). Effect of dried pumpkin powder on physical, chemical, and sensory properties of noodles. Internasional Journal of Advances in Science Engineering and Technology, 5(1), 14-18.

Badan Pusat Statistik Kota Semarang (BPS). (2017). Kecamatan Semarang Utara Dalam Angka tahun 2017. Kota Semarang: Badan Pusat Statistik.

Badan Standardisasi Nasional (BSN). (2015). Mie Kering. SNI 8217:2015. Jakarta (ID) : BSN

Billina, A., Waluyo, S., \& Suhandy, D. (2014). Kajian sifat fisik mie basah dengan penambahan rumput laut. Jurnal Teknik Pertanian Lampung, 4(2), 109-116.

Biyumna, U. L., Windrati, W. S, \& Diniyah, N. (2017). Karakteristik mie kering terbuat dari tepung sukun (Artocarpus altilis) dan penambahan telur. Jurnal Agroteknologi, 11(1), 12-34.doi: 10.19184/jagt.v11i1.5440

Chandrani, W. A. Y., and Wattevidanage, J. (2016). Species composition and fatty acid profile in family Leiognathidae sampled from west coast of Sri Lanka. International Journal of Science Arts and Commerce, 1(9), 108-123. 
Charles, A. L., Chang, Y. H., Ko, W. C., Sriroth, K., \& Huang, T. C. (2005). Influence of amylopectin structure and amylose content on the gelling properties of five cultivars of cassava starches. Journal of Agricultural and Food Chemistry, 53(7), 2717-2725. doi: 10.1021/jf048376+

Desai, A., Brennan, M. A., \& Brennan, C. S. (2018). The effect of semolina replacement with protein powder from fish (Pseudophycis bachus) on the physicochemical characteristics of pasta. Journal of Food Science and Technology, 89, 52-57. doi: 10.1016/j.Iwt.2017.10.023

Fauzi, M., Diniyah, N., Rusdianto, A. S., \& Kuliahsari, D. E. (2017). Penggunaan vitamin C dan suhu pengeringan pada pembuatan chip (irisan kering) labu kuning LA3 (Cucurbita moschata). Jurnal Penelitian Pascapanen Pertanian, 14(2), 108-115. doi: 10.21082/jpasca.v14n2.2017.108-115

Gumolung, D. (2019). Analisis proksimat tepung daging buah labu kuning (Cucurbita moschata). Fullerene Journal of Chemistry, 4(2), 108-115.

Irsalina. R., Lestari, S. D., \& Herpandi, H. (2016). Karakteristik fisiko-kimia dan sensori mie kering dengan penambahan tepung ikan motan (Thynnichthys thynnoides). Jurnal Fishtech, 5(1), 3242. doi : $10.36706 /$ fishtech.v5i1.3516

Jang, H. L, Bae, I. Y., \& Lee, H. G. (2015). In vitro starch digestibility of noodles with various cereal flours and hydrocolloids. Journal of Food Sciences and Technology, 63(1), 122-128. doi: 10.1016/ j.Iwt.2015.03.029

Kementerian Kelautan \& Perikanan. (2018). Refleksi 2018 \& Outlook 2019. Jakarta: KKP.

Kementerian Pertanian. (2018). Statistik Konsumsi Pangan Tahun 2018.

Khan, M. A., Mahesh, C., Vineeta, P., Sharma, G. K., \& Semwal. A. D. (2019). Effect of pumpkin flour on the rheological characteristics of wheat flour and on biscuit quality. Journal of Food Processing \& Technology, 10(10), 1-6. doi: 10.35248/21577110.19.10.814

Kong, S., Kim, D. J., Oh, S. K., Choi, I. S., Jeong, H. S., \& Lee, J. (2012). Black rice bran as an ingredient in noodles: chemical and functional evaluation. Journal of Food Science, 77(3), 303-307. doi: 10.1111/j.17503841.2011.02590.x

Kuchtová, V., Karovièová, J., Kohajdová, Z., \& Minarovièová, L. (2016). Chemical composition and functional properties of pumpkin pomaceincorporated crackers. Journal of Acta Chimica Slovaca, 9(1), 54-57. doi: 10.1515/acs-2016-0009

Lanyala, I. A., Rahim, A., \& Samudin, S. (2018). Karakteristik fisikokimia dan organoleptik mie jagung pada rasio pati jagung dengan tepung terigu. Jurnal Agrotekbis, 6(5), 662-669.

Larmond, E. (1973). Methods for Sensory Evaluation of Food. Ottawa: Canada Department of Agriculture.

Mardiah, M., Andini, S. F., Hafiani, N., Fitrilia, T., \& Widowati, S. (2020). Effect of drying method on physicochemical properties of pumpkin flour.
International Journal of Advanced Science and Technology, 29(7), 3174-3189.

Nakhon, P. P. S., Jangchud, K., Jangchud, A., \& Prinyawiwatkul, W. (2017). Comparisons of physicochemical properties and antioxidant activities among pumpkin (Cucurbita moschata L.) flour and isolated starches from fresh pumpkin or flour. International Journal of Food Science and Technology, 52(11), 2436-2444. doi: 10.1111/ijfs.13528

Nuringtyas, D. P., \& Adi, A. C. (2017). Mutu organoleptik, kandungan protein dan betakaroten mie substitusi ikan rucah dan ubi jalar kuning. Jurnal Media Gizi Indonesia, 12(2), 164-172. doi: 10.20473/ mgi.v12i2.164-172

Pang, C. J., Noerhartati, E., \& Rejeki, F. S. (2013). Optimasi proses pengolahan mi ikan tongkol (Euthynnus affinis). Jurnal REKA Agroindustri, 1(1), 1-7.

Pratama, I. A., \& Nisa, F. C. (2014). Formulasi mie kering dengan subsitusi tepung kimpul (Xanthosoma sagittifolium) dan penambahan tepung kacang hijau (Phaseolus radiatus L.). Jurnal Pangan dan Agroindustri, 2(4), 101-112.

Priatni, S., Ratnaningrum, D., Kosasih, W., Sriendah, E., Srikandace, Y., Rosmalina, T., \& Pudjiraharti, S. (2018). Protein and fatty acid profile of marine fishes from Java Sea, Indonesia. Journal of Biodiversitas, 19(5), 1737-1742. doi: 10.13057/biodiv/d190520

Purwandari, U., Khoiri, A., Muchlis, M., Noriandita, B., Zeni, N. F., Lisdayana, N., \& Fauziyah, E. (2014). Textural, cooking quality, and sensory evaluation of gluten-free noodle made from breadfruit, konjac, or pumpkin flour. International Food Research Journal, 21(4), 1623-1627.

Purwanto, C. C., Ishartani, D., \& Rahadian, D. (2013). Kajian sifat fisik dan kimia tepung labu kuning (Cucurbita maxima) dengan perlakuan blanching dan perendaman natrium metabisulfit $\left(\mathrm{Na}_{2} \mathrm{~S}_{2} \mathrm{O}_{5}\right)$. Jurnal Teknosains Pangan, 2(2), 121-130.

Santosa, D. D. S. (2009). Pemanfaatan tepung premix berbahan dasar mutan sorgum $\mathrm{ZH}-30$ untuk industri pembuatan adonan dan mie kering. Jurnal IImiah Aplikasi Isotop dan Radiasi, 5(1), 1-21.

Setiyoko, A., Nugraheni, \& Hartutik, S. (2018). Karakteristik mie basah dengan substitusi tepung bengkuang termodifikasi Heat Moisture Treatment (HMT). Jurnal Teknologi Pertanian Andalas, 22(2), 102-110. doi: 10.25077/jtpa.22.2.102-110.2018

Setyani, S., Astuti, S., \& Florentina. (2017). Substitusi tepung tempe jagung pada pembuatan mie basah. Jurnal Teknologi Industri \& Hasil Pertanian, 22(1), 1-10. doi: http://dx.doi.org/10.23960/jtihp.v22i1.1-10

Wongsagonsup, R., Kittisuban, P., Yaowalak, A., \& Suphantharika, M. (2015). Physical and sensory qualities of composite wheat-pumpkin flour bread with addition of hydrocolloids. International Food Research Journal, 22(2), 745-752.

Yulianti. (2018). Pengaruh penambahan tepung ikan cakalang pada mie kering yang bersubstitusi tepung ubi jalar. Gorontalo Agriculture Technology Journal, 1(2), 8-15. doi: 10.32662/gatj.v1i2.418 
Zuhri, N. M., Swastawati, F., \& Wijayanti, I. (2014). Pengkayaan kualitas mi kering dengan penambahan tepung daging ikan lele dumbo
(Clarias gariepinus) sebagai sumber protein. Jurnal Pengolahan dan Bioteknologi Hasil Perikanan, 3(4), 119-126. 